\title{
Oxygen as a driving gas for nebulisers: safe or dangerous?
}

\author{
K A GUNAWARDENA， B PATEL， I A CAMPBELL，J B MACDONALD， A P SMITH
}

\begin{abstract}
Changes in blood gas tensions occurring when $100 \%$ oxygen or air was used as the driving gas for nebulised salbutamol were studied in 23 patients with severe airways obstruction. The patients fell into three groups: nine had chronic bronchitis and emphysema with carbon dioxide retention, seven had emphysema and chronic bronchitis without carbon dioxide retention, and seven had severe asthma (no carbon dioxide retention). When oxygen was used as the driving gas patients who retained carbon dioxide showed a mean rise of $1.03 \mathrm{kPa}(7.7 \mathrm{~mm} \mathrm{Hg})$ in their pressure of carbon dioxide $\left(\mathrm{Pco}_{2}\right)$ after 15 minutes $(\mathrm{p}<0.001)$ but the Pco. returned to baseline values within 20 minutes of stopping the nebuliser. The other two groups showed no rise in $\mathrm{Pco}_{2}$ with oxygen. When air was used as the driving gas none of the groups became significantly more hypoxic.

Although it is safe to use oxygen as the driving gas for nebulisers in patients with obstructive airways disease with normal Pco, caution should be exercised in those who already have carbon dioxide retention.
\end{abstract}

\section{Introduction}

Nebulised bronchodilators are now extensively used in the management of severe asthma and exacerbations of chronic obstructive airways disease. In hospital practice there are driving gas for nebulised bronchodilators in patients with severe asthma hypoxia may be aggravated. ${ }^{5} 6$

The aim of this study was therefore to compare the changes in blood gas tensions that occur during and after the use of nebulisers with either $100 \%$ oxygen or air as a source for the driving gas in patients with asthma or exacerbations of chronic obstructive airways disease. In particular, we wanted to know whether it is safe to use $100 \%$ oxygen as a driving gas for nebulised bronchodilators for patients in chronic respiratory failure with carbon dioxide retention.

\section{Patients and methods}

We studied three categories of patients admitted to our wards with severe airways obstruction-namely, (a) patients with emphysema and chronic bronchitis without carbon dioxide retention $(\mathbf{n}=7)$; (b) patients with chronic bronchitis and emphysema with carbon dioxide retention $(n=9)$; (c) patients with acute severe asthma without carbon dioxide retention $(n=7)$.

The diagnosis of chronic bronchitis and emphysema was based on a strong history of smoking, chronic production of sputum, radiological evidence of emphysema, and severe airflow obstruction with minimal reversibility. Patients with asthma were mostly non-smokers and had documented evidence of reversible airflow obstruction. In doubtful cases the single breath transfer factor for carbon monoxide and the transfer coefficient (KCO) were determined, and if these were low the patient was categorised as having emphysema. Table I gives the age, sex, percentage of predicted normal peak expiratory flow rate, and the blood gas tensions of the patients at the time of study.

TABLE I-Details of patients on day of study. (Ranges in parentheses)

\begin{tabular}{|c|c|c|c|c|c|c|}
\hline & No of cases & $M: F$ & Mean age (years) & Mean $\mathrm{Po}_{2}(\mathrm{kPa})$ & Mean $\mathrm{PcO}_{2}(\mathrm{kPa})$ & $\begin{array}{l}\text { Mean \% of predicted } \\
\text { peak expiratory flow rate }\end{array}$ \\
\hline $\begin{array}{l}\text { Chronic obstructive airways disease without } \\
\text { carbon dioxide retention }\end{array}$ & 7 & $5: 2$ & $70(63-76)$ & $9 \cdot 47(9 \cdot 07-10 \cdot 40)$ & $5 \cdot 07(4 \cdot 40-5 \cdot 47)$ & $38(11-57)$ \\
\hline $\begin{array}{l}\text { Chronic obstructive airways disease with carbon } \\
\text { dioxide retention } \\
\text { Asthma }\end{array}$ & $\begin{array}{l}9 \\
7\end{array}$ & $\begin{array}{l}6: 3 \\
1: 6\end{array}$ & $\begin{array}{l}65(58-74) \\
50(36-62)\end{array}$ & $\begin{array}{l}6 \cdot 27(4 \cdot 13-7 \cdot 33) \\
9 \cdot 73(5 \cdot 87-12 \cdot 80)\end{array}$ & $\begin{array}{l}7 \cdot 60(6 \cdot 67-9 \cdot 87) \\
4 \cdot 40(3 \cdot 73-5 \cdot 07)\end{array}$ & $\begin{array}{l}29(19-41) \\
49(15-78)\end{array}$ \\
\hline
\end{tabular}

Conversion: SI to traditional units- $\mathrm{Po}_{2}: 1 \mathrm{kPa} \approx 7.5 \mathrm{~mm} \mathrm{Hg} \mathrm{PCO}_{2}: 1 \mathrm{kPa} \approx 7.5 \mathrm{~mm} \mathrm{Hg}$

several options for the driving gases for use with nebulisers, the most convenient source being the piped oxygen available at the bedside. Alternatively, compressed air may be used, either from a cylinder or from an electrically driven portable air compressor. For efficient nebulisation gases must be delivered at a flow of around $8 \mathrm{l} / \mathrm{min}$ for periods up to 15 minutes. ${ }^{1}$ When $100 \%$ oxygen is used at such high flow rates in patients with chronic respiratory failure there is the possibility of increasing their carbon dioxide retention. ${ }^{2-4}$ Conversely, if air is used as the

Llandough Hospital, Penarth, South Glamorgan

K A GUNAWARDENA, MD (CEYLON), MRCP, registrar in thoracic medicine B PATEL, MB, CHB, senior house officer in cardiothoracic medicine

I A CAMPBELL, MD, FRCPED, consultant in thoracic medicine

A P SMITH, MD, MRCP, consultant in thoracic medicine

North Ayrshire District Hospital, Kilmarnock

J B MACDONALD, MD, MRCP, consultant physician

Correspondence and requests for reprints to: $\mathrm{Dr} \mathrm{K}$ A Gunawardena, Thoracic Outpatient Department, Llandough Hospital, Penarth, South Glamorgan CF6 1XX.
All studies were done in the wards when the patient's clinical condition had become relatively stable in response to initial treatment. None of the patients had received nikethamide or doxapram in the four hours before the study. Nebulised bronchodilators were also withheld for four hours but the patients continued with their oral or intravenous steroids, antibiotics, oral slow release aminophylline, or intravenous aminophylline and physiotherapy on the day of the study. One patient with emphysema and chronic bronchitis without carbon dioxide retention had been receiving $40 \%$ oxygen for 36 hours before the study and was allowed to continue with it; all others breathed air for at least one hour before the study.

Patients were informed of the purpose and nature of the study and their consent obtained. A cannula (20 gauge Quick-cath or a 19 gauge Venflon) was introduced into the radial or brachial artery percutaneously under local anaesthesia. Arterial blood sampling was done at minus five minutes, zero time (start of the nebuliser), every five minutes during the period of nebulisation up to 15 minutes, and at five, 10 , and 20 minutes from the end of nebulisation. Salbutamol respirator solution $(0.5 \%)$ was used as the bronchodilator, given as $1 \mathrm{ml}$ diluted to $5 \mathrm{ml}$ with sterile $0.9 \%$ saline, and administered by a Hudson or Life-line nebuliser with the mask provided with the commercial nebuliser kit. One hundred per cent oxygen was used as the driving gas from the piped oxygen supply or from a compressed gas cylinder (four patients) at a flow of $81 / \mathrm{min}$. Air was delivered by 
an air compressor (Inspiron or Portaneb) or from a compressed gas cylinder (four patients) at a flow of $8 \mathrm{l} / \mathrm{min}$. When the compressors were used the respirator solution was diluted to only $3.5 \mathrm{ml}$ to ensure complete delivery of the drug within 15 minutes.

Patients were allocated at random to receive either oxygen or air as the driving gas during the first nebulisation. The arterial cannula was left in situ after flushing with heparinised saline. Two to four hours after the initial nebulisation the alternative driving gas was used and the blood sampling repeated.

All blood samples were stored in ice immediately after removal. Blood gas estimations were done in an ABL-2 blood gas machine (Radiometer, Copenhagen) within five minutes of removal of the last sample.

Statistical analysis was by paired $t$ tests. The study protocol was approved by the local ethical committees.

\section{Results}

Table II gives the mean values (and SEM) of pressure of oxygen $\left(\mathrm{Po}_{2}\right)$ and pressure of carbon dioxide $\left(\mathrm{PCO}_{2}\right)$ before, during, and after the nebulisations for the three categories of patients, using the two different driving gases. The figure illustrates the sequential changes. The most significant change was found in the patients with carbon dioxide retention. They showed a progressive rise in $\mathrm{PCO}_{2}$ during the period of nebulisation when oxygen was used as the driving gas, the mean difference reaching $1.03 \mathrm{kPa}(7.7 \mathrm{~mm} \mathrm{Hg})$ at 15 minutes $(\mathrm{p}<0.001)$. The maximum rise observed in any individual patient was $2.94 \mathrm{kPa}(22.0 \mathrm{~mm} \mathrm{Hg})$ - that is, a rise of $\mathrm{PCO}_{2}$ from $8.13 \mathrm{kPa}$ $(61.0 \mathrm{~mm} \mathrm{Hg})$ at the beginning of the study to $11.07 \mathrm{kPa}(83.0 \mathrm{~mm} \mathrm{Hg})$ at 10 minutes of nebulisation. When the nebuliser was discontinued the $\mathrm{PCO}_{2}$ fell rapidly and reached baseline values within 20 minutes in all patients.

In the group with carbon dioxide retention there was also a small rise in $\mathrm{PCO}_{2}(0.31-0.36 \mathrm{kPa} ; 2.3-2.7 \mathrm{~mm} \mathrm{Hg})$ during the five minute rest period from the insertion of the cannula (minus five minutes) to the time of beginning the nebuliser (zero time), significant at the $5 \%$ level.

The other two groups showed no statistically significant change in the two baseline values, nor did they show any rise in $\mathrm{PCO}_{2}$ when oxygen was used as the driving gas. In none of the groups did we observe worsening of hypoxia during or after nebulisation with air.

\section{Discussion}

Piped or compressed $100 \%$ oxygen is often used in hospitals for driving nebulisers to deliver bronchodilators to patients with severe airways obstruction. Our ward sisters have occasionally
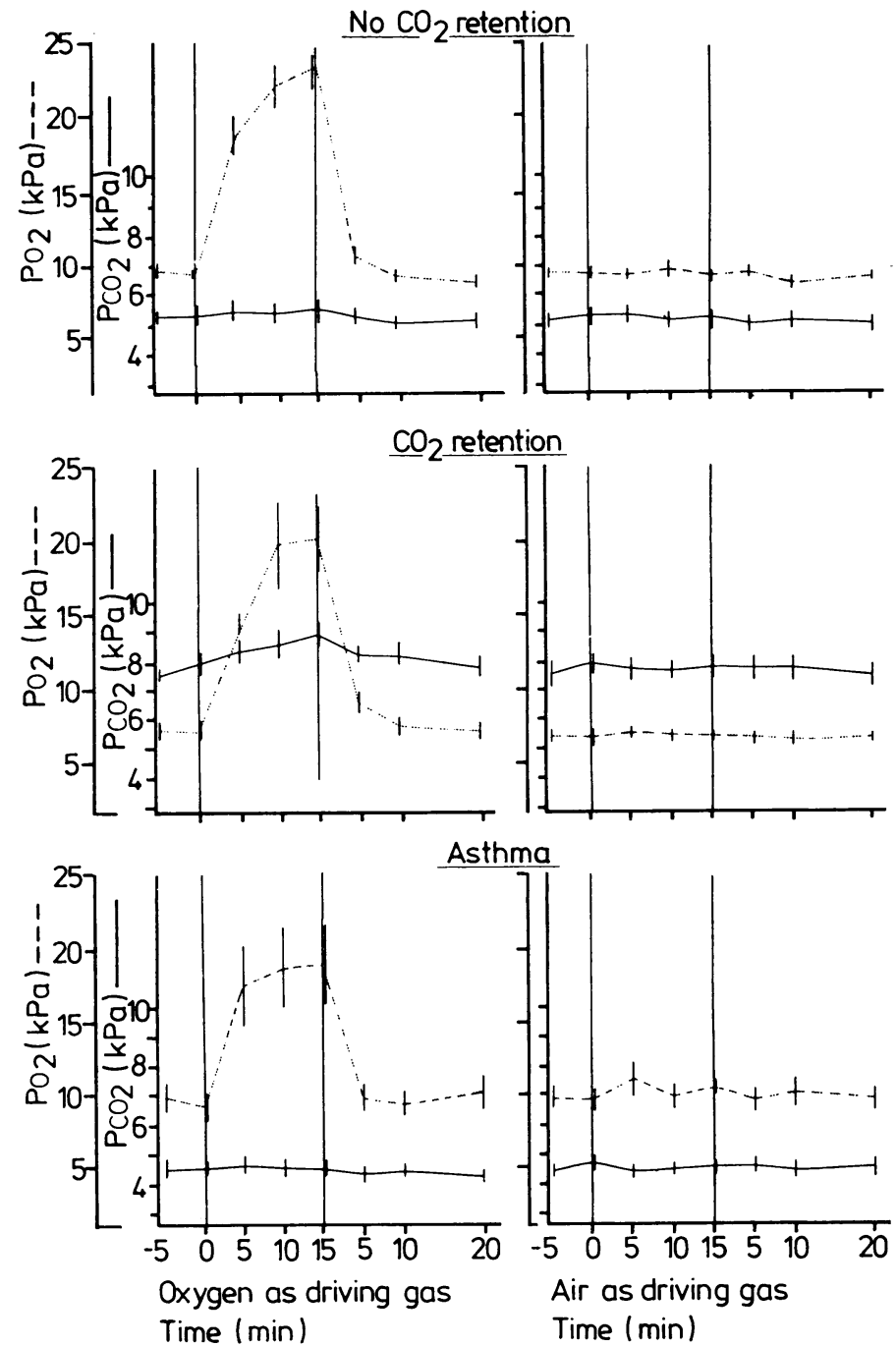

Mean $\mathrm{Po}_{2}(--)^{-}$and $\mathrm{PCO}_{2}(-)$ changes for three groups of patients. Nebuliser used between 0 and +15 minutes (long vertical lines). Short vertical lines at each sampling point indicate error bars (2 SEM). Scale marked 5-25 is for $\mathrm{PO}_{2}$; that marked 3-10 is for $\mathrm{PCO}_{2}$. Progressive rise in $\mathrm{PCO}_{2}$ seen only in group with carbon dioxide retention when oxygen used as driving gas.

TABLE II-Blood gas changes during and after nebulised salbutamol with oxygen and air as driving gases in different categories of patients with airways obstruction

\begin{tabular}{|c|c|c|c|c|c|c|c|c|c|c|c|c|c|c|c|c|}
\hline \multirow[b]{3}{*}{ Time (min) } & \multicolumn{8}{|c|}{ Oxygen as driving gas } & \multicolumn{8}{|c|}{ Air as driving gas } \\
\hline & \multicolumn{2}{|c|}{ Before } & \multicolumn{3}{|c|}{ During } & \multicolumn{3}{|c|}{ After } & \multicolumn{2}{|c|}{ Before } & \multicolumn{3}{|c|}{ During } & \multicolumn{3}{|c|}{ After } \\
\hline & -5 & 0 & +5 & +10 & +15 & 5 & 10 & 20 & -5 & 0 & +5 & +10 & +15 & 5 & 10 & 20 \\
\hline \multicolumn{17}{|c|}{ Chronic obstructive airways disease without carbon dioxide retention $(n=7)$} \\
\hline $\mathrm{Po}_{(\mathrm{kPa})}\left\{\begin{array}{l}\text { Mean } \\
\mathrm{SEM}\end{array}\right.$ & $\begin{array}{l}9 \cdot 56 \\
0 \cdot 35\end{array}$ & $\begin{array}{l}9 \cdot 21 \\
0 \cdot 28\end{array}$ & $\begin{array}{r}18.63 \\
1.35\end{array}$ & $\begin{array}{r}22 \cdot 00 \\
1 \cdot 46\end{array}$ & $\begin{array}{r}23 \cdot 29 \\
1.15\end{array}$ & $\begin{array}{r}10.67 \\
0.50\end{array}$ & $\begin{array}{l}9 \cdot 29 \\
0 \cdot 38\end{array}$ & $\begin{array}{l}8 \cdot 84 \\
0 \cdot 38\end{array}$ & $\begin{array}{l}9 \cdot 41 \\
0 \cdot 25\end{array}$ & $\begin{array}{l}9 \cdot 39 \\
0 \cdot 28\end{array}$ & $\begin{array}{l}9 \cdot 29 \\
0 \cdot 30\end{array}$ & $\begin{array}{l}9 \cdot 60 \\
0.53\end{array}$ & $\begin{array}{l}9 \cdot 25 \\
0 \cdot 41\end{array}$ & $\begin{array}{l}9 \cdot 55 \\
0 \cdot 36\end{array}$ & $\begin{array}{l}8.99 \\
0.35\end{array}$ & $\begin{array}{l}9 \cdot 29 \\
0 \cdot 29\end{array}$ \\
\hline$\underset{(\mathrm{kPa})}{\mathrm{Pco}_{2}}\left\{\begin{array}{l}\text { Mean } \\
\mathrm{SEM}\end{array}\right.$ & $\begin{array}{l}5 \cdot 24 \\
0 \cdot 19\end{array}$ & $\begin{array}{l}5 \cdot 25 \\
0 \cdot 28\end{array}$ & $\begin{array}{l}5 \cdot 43 \\
0 \cdot 30\end{array}$ & $\begin{array}{l}5 \cdot 33 \\
0 \cdot 31\end{array}$ & $\begin{array}{l}5 \cdot 53 \\
0 \cdot 35\end{array}$ & $\begin{array}{l}5 \cdot 25 \\
0 \cdot 24\end{array}$ & $\begin{array}{l}5 \cdot 05 \\
0 \cdot 21\end{array}$ & $\begin{array}{l}5 \cdot 12 \\
0 \cdot 24\end{array}$ & $\begin{array}{l}5 \cdot 08 \\
0 \cdot 22\end{array}$ & $\begin{array}{l}5 \cdot 25 \\
0 \cdot 28\end{array}$ & $\begin{array}{l}5 \cdot 28 \\
0 \cdot 27\end{array}$ & $\begin{array}{l}5 \cdot 09 \\
0 \cdot 28\end{array}$ & $\begin{array}{l}5 \cdot 19 \\
0 \cdot 29\end{array}$ & $\begin{array}{l}4 \cdot 93 \\
0 \cdot 23\end{array}$ & $\begin{array}{l}5.07 \\
0.29\end{array}$ & $\begin{array}{l}4 \cdot 92 \\
0 \cdot 23\end{array}$ \\
\hline \multicolumn{17}{|c|}{ Chronic obstructive airways disease with carbon dioxide retention $(n=9)$} \\
\hline $\mathrm{Po}_{(\mathrm{kPa})}\left\{\begin{array}{l}\text { Mean } \\
\mathrm{SEM}\end{array}\right.$ & $\begin{array}{l}6 \cdot 77 \\
0 \cdot 45\end{array}$ & $\begin{array}{l}6 \cdot 65^{\dagger} \\
0 \cdot 47^{-}\end{array}$ & $\begin{array}{r}13.52 \\
1.57\end{array}$ & $\begin{array}{r}19 \cdot 39 \\
2 \cdot 91\end{array}$ & $\begin{array}{r}19 \cdot 79 \\
2 \cdot 27\end{array}$ & $\begin{array}{l}8.63 \\
0.66\end{array}$ & $\begin{array}{l}7.08 \\
0.50\end{array}$ & $\begin{array}{l}6.72 \\
0.56\end{array}$ & $\begin{array}{l}6 \cdot 31 \\
0 \cdot 42\end{array}$ & $\begin{array}{l}6 \cdot 20 \\
0 \cdot 38\end{array}$ & $\begin{array}{l}6.53^{*} \\
0.39\end{array}$ & $\begin{array}{l}6 \cdot 37 \\
0 \cdot 37\end{array}$ & $\begin{array}{l}6 \cdot 27 \\
0 \cdot 38\end{array}$ & $\begin{array}{l}6 \cdot 17 \\
0.43\end{array}$ & $\begin{array}{l}6.01 \\
0.36\end{array}$ & $\begin{array}{l}6 \cdot 08 \\
0 \cdot 29\end{array}$ \\
\hline$\underset{(\mathrm{kPa})}{\mathrm{PCO}_{2}}\left\{\begin{array}{l}\text { Mean } \\
\mathrm{SEM}\end{array}\right.$ & $\begin{array}{l}7 \cdot 29 \\
0 \cdot 22\end{array}$ & $\begin{array}{l}7 \cdot 60^{+} \\
0 \cdot 29\end{array}$ & $\begin{array}{l}8 \cdot 04^{* *} \\
0 \cdot 39\end{array}$ & $\begin{array}{l}8 \cdot 28^{*} \\
0 \cdot 47\end{array}$ & $\begin{array}{l}8.63^{* * * *} \\
0.35\end{array}$ & $\begin{array}{l}7 \cdot 92 \\
0 \cdot 29\end{array}$ & $\begin{array}{l}7 \cdot 91 \\
0 \cdot 33\end{array}$ & $\begin{array}{l}7 \cdot 48 \\
0 \cdot 23\end{array}$ & $\begin{array}{l}7 \cdot 24 \\
0 \cdot 37\end{array}$ & $\begin{array}{l}7 \cdot 60 \dagger \\
0.31\end{array}$ & $\begin{array}{l}7.41^{*} \\
0.35\end{array}$ & $\begin{array}{l}7 \cdot 28^{*} \\
0.29\end{array}$ & $\begin{array}{l}7 \cdot 48 \\
0 \cdot 38\end{array}$ & $\begin{array}{l}7 \cdot 43 \\
0.42\end{array}$ & $\begin{array}{l}7 \cdot 44 \\
0 \cdot 40\end{array}$ & $\begin{array}{l}7 \cdot 20^{* *} \\
0 \cdot 34\end{array}$ \\
\hline \multicolumn{17}{|c|}{ Asthma $(n=7)$} \\
\hline 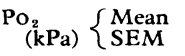 & $\begin{array}{l}9 \cdot 89 \\
0 \cdot 98\end{array}$ & $\begin{array}{l}9 \cdot 22 \\
0 \cdot 89\end{array}$ & $\begin{array}{r}17 \cdot 52 \\
2 \cdot 84\end{array}$ & $\begin{array}{r}18 \cdot 78 \\
2 \cdot 83\end{array}$ & $\begin{array}{r}19 \cdot 05 \\
2 \cdot 62\end{array}$ & $\begin{array}{l}9 \cdot 71 \\
0 \cdot 75\end{array}$ & $\begin{array}{l}9 \cdot 37 \\
0 \cdot 75\end{array}$ & $\begin{array}{r}10 \cdot 15 \\
1 \cdot 09\end{array}$ & $\begin{array}{l}9 \cdot 81 \\
0 \cdot 72\end{array}$ & $\begin{array}{l}9 \cdot 64 \\
0.69\end{array}$ & $\begin{array}{r}10 \cdot 99 \\
1 \cdot 10\end{array}$ & $\begin{array}{l}9 \cdot 79 \\
0 \cdot 80\end{array}$ & $\begin{array}{r}10 \cdot 47 \\
0.41\end{array}$ & $\begin{array}{l}9 \cdot 60 \\
0 \cdot 76\end{array}$ & $\begin{array}{r}10 \cdot 21 \\
1.03\end{array}$ & $\begin{array}{l}9 \cdot 62 \\
0 \cdot 82\end{array}$ \\
\hline$\underset{(\mathrm{kPa})}{\mathrm{PCO}_{2}}\left\{\begin{array}{l}\text { Mean } \\
\mathrm{SEM}\end{array}\right.$ & $\begin{array}{l}4 \cdot 49 \\
0 \cdot 30\end{array}$ & $\begin{array}{l}4 \cdot 53 \\
0 \cdot 21\end{array}$ & $\begin{array}{l}4 \cdot 65 \\
0 \cdot 27\end{array}$ & $\begin{array}{l}4 \cdot 57 \\
0 \cdot 23\end{array}$ & $\begin{array}{l}4 \cdot 48 \\
0 \cdot 26\end{array}$ & $\begin{array}{l}4 \cdot 32 \\
0 \cdot 24\end{array}$ & $\begin{array}{l}4 \cdot 44 \\
0 \cdot 22\end{array}$ & $\begin{array}{l}4 \cdot 21 \\
0 \cdot 23\end{array}$ & $\begin{array}{l}4 \cdot 42 \\
0 \cdot 19\end{array}$ & $\begin{array}{l}4 \cdot 65 \\
0 \cdot 19\end{array}$ & $\begin{array}{l}4 \cdot 48 \\
0 \cdot 21\end{array}$ & $\begin{array}{l}4 \cdot 51 \\
0 \cdot 20\end{array}$ & $\begin{array}{l}4 \cdot 58 \\
0 \cdot 25\end{array}$ & $\begin{array}{l}4 \cdot 61 \\
0 \cdot 23\end{array}$ & $\begin{array}{l}4 \cdot 44 \\
0 \cdot 24\end{array}$ & $\begin{array}{l}4.55 \\
0.25\end{array}$ \\
\hline
\end{tabular}

******Difference compared with baseline value at time $0:{ }^{*} \mathrm{p}<0.05 ; * * \mathrm{p}<0.01 ;{ }^{* * *} \mathrm{p}<\mathbf{0 . 0 0 1}$

†Difference compared with value at time $-5: \mathrm{p}<0.05$.

$\mathrm{p}$ Values for $\mathrm{Po}_{2}$ changes with oxygen omitted.

Conversion: SI to traditional units- $\mathrm{PO}_{2}: 1 \mathrm{kPa} \approx 7.5 \mathrm{~mm} \mathrm{Hg} . \mathrm{Pco}_{2}: 1 \mathrm{kPa} \approx 7.5 \mathrm{~mm} \mathrm{Hg}$. 
complained that some patients with respiratory failure develop signs of carbon dioxide intoxication when oxygen is used to drive the nebulisers. We could find no reported studies of changes in blood gas tensions in such patients.

We conclude that patients with chronic obstructive airways disease without carbon dioxide retention (broadly speaking, the "pink puffer" type) and patients with asthma show no rise in $\mathrm{PCO}_{2}$ when oxygen is used as the driving gas. Chronic bronchitics with carbon dioxide retention, however, show a progressive rise in $\mathrm{PCO}_{2}$ when oxygen is used and in individual patients this may be as much as $2.94 \mathrm{kPa}(22.0 \mathrm{~mm} \mathrm{Hg})$ within the 15 minute period of nebulisation. This rise, however, is temporary and all patients reach their baseline $\mathrm{PCO}_{2}$ within 20 minutes of discontinuing the nebuliser. If the nebuliser mask with the oxygen were left on longer (as may well happen in a busy ward) possibly their $\mathrm{PCO}_{2}$ would rise to a level sufficient to cause carbon dioxide narcosis. Thus the observation by our ward sisters would seem to be valid.

On the other hand, none of the patients showed worsening hypoxia when air was used for nebulisation. Hypoxia after treatment with a bronchodilator has been reported with intravenous aminophylline,,$^{5}$ subcutaneous adrenaline, ${ }^{8}$ and inhaled isoprenaline, ${ }^{5} 9$ but was not found with the newer beta agonists such as terbutaline (subcutaneous) ${ }^{10}$ and salbutamol aerosol. ${ }^{9}$ Our observations are in keeping with the latter findings. It should be noted that the asthmatics, in particular, were not severely hypoxic at the beginning of the study; all but one patient had a $\mathrm{Po}_{2}$ of over $9.2 \mathrm{kPa}(69.0 \mathrm{~mm} \mathrm{Hg})$. It is not possible to extrapolate from this study to the case of the more hypoxic asthmatic using an air driven nebuliser. Further studies are under way to investigate this point.

An interesting observation was the small but statistically significant rise in $\mathrm{PCO}_{2}$ that occurred only in the group with carbon dioxide retention simply with a five minute rest in a semireclining position. Even the subtle degree of hypoventilation induced by semirecumbent rest after arterial cannulation was enough to alter the blood gas tensions in this group but not in the other two groups.

From our findings we draw the following conclusions about the driving gases to be used with nebulisers.

Firstly, in patients with asthma or chronic obstructive airways disease without carbon dioxide retention either air or oxygen may safely be used. As most patients in this group tend to be hypoxic it is preferable to use oxygen. If they had required continuous oxygen for hypoxia it is sensible to use oxygen to drive the nebuliser.

Secondly, in patients with chronic bronchitis and emphysema with carbon dioxide retention $100 \%$ oxygen should be used only under close supervision, and if used should be given for the shortest possible period, preferably less than 10 minutes. It would be safer, however, to use air as the driving gas unless the patient is so hypoxic that he needs continuous oxygen to maintain acceptable blood gas values. In such patients the driving gas should be the appropriate gas mixture $(24 \%$ or $28 \%$ oxygen), delivered at a flow of around $81 / \mathrm{min}$. Alternatively, oxygen might be used for shorter periods (five to 10 minutes) using an appropriate volume and dilution of the bronchodilator so that the required dose of the drug is delivered within that period.

Thirdly, there can be little place for prescribing a domiciliary oxygen supply solely for the purpose of driving a nebuliser. Apart from being expensive and inefficient, it might be dangerous in some patients with carbon dioxide retention. For domiciliary nebuliser treatment a portable air compressor should suffice in most cases. Patients known to be prone to severe attacks of asthma should, however, also be provided with an oxygen cylinder and an MC or similar face mask, since the inhalation of a bronchodilator aerosol will not in itself correct serious hypoxaemia.

We did not come across any patients with asthma and carbon dioxide retention during the period of our study and so cannot draw conclusions about this type of patient.

We thank Dr G R Jones and Dr B H Davies for allowing us access to some of their patients, and the staff at the biochemistry laboratory, Llandough Hospital, for the blood gas analyses.

\section{References}

1 Clay M, Pavia D, Newman SP, Clarke SW. Efficiency of jet nebulisers in the production of therapeutic aerosols. Thorax 1982;37:788. (BTA summer meeting abstract.)

2 Westlake EK, Simpson T, Kaye M. Carbon dioxide narcosis in emphysema. $Q \mathcal{F}$ Med 1955;24:155-73.

${ }^{3}$ Sieker HO, Hickam JB. Carbon dioxide intoxication: the clinical syndrome, its aetiology and management with particular reference to the use of mechanical respiration. Medicine (Baltimore) 1956;35:389-423.

${ }^{4}$ Comroe JH, Bahnson ER, Coates EO. Mental changes occurring in chronically anoxemic patients during oxygen therapy. f $A M A 1950$; 143: $1044-8$

${ }^{5}$ Tai E, Read J. Response of blood gas tensions to aminophylline and isoprenaline in patients with asthma. Thorax 1967;22:543-9.

${ }^{6}$ Flenley DC. Blood gas tensions in severe asthma. Proc $R$ Soc Med 1971; 64:1149-51.

${ }^{7}$ Rees HA, Borthwick RC, Millar JS, Donald KW. Aminophylline in bronchial asthma. Lancet 1967;ii:1167-9.

${ }^{8}$ Rees HA, Millar JS, Donald KW. A study of the clinical course and blood gas tensions of patients in status asthmaticus. $Q \mathcal{F}$ Med 1968 ; 37:541-61.

${ }^{9}$ Palmer KNV, Legge JS, Hamilton WFD, Diament ML. Comparison of effect of salbutamol and isoprenaline on spirometry and blood gas tensions in bronchial asthma. $\mathrm{Br}$ Med $\mathcal{f} 1970 ; \mathrm{ii}: 23-4$.

${ }^{10} \mathrm{Da}$ Costa J, Hedstrand U. The effect of a new sympathomimetic betareceptor stimulating drug (terbutaline) on aerterial blood gases in bronchial asthma. Scand $\mathcal{F}$ Respir Dis 1970;51:212-7.

(Accepted 21 November 1983)
ONE HUNDRED YEARS AGO The movement for preserving and extending the rights of the public to open spaces has now taken such fair hold of the community, that we may expect to find in the future that the encroachments of railway companies and of builders will be more narrowly scrutinised than was the case in past days. We are glad to notice that, in the coming session of Parliament, a Bill will be introduced, having for its object the placing of those parts of the Malvern Hills which consist of common lands in the hands of conservators, who shall be empowered to prevent encroachments thereon, either by the rich or poor. This lovely stretch of hill-country seems in the past to have been the prey of neighbouring landowners and those exercising manorial rights, who have been gradually filching from the public the common land over which, from time immemorial the people have been wont to roam.-A meeting has been held at Hampstead, at which it was decided to inaugurate a movement for securing additional open land on the borders of Hampstead Heath, by the purchase of various plots of land otherwise likely to fall into the builders' hands. It was suggested that the cost could be met by public subscription, and the help of the City Corporation and the Metropolitan Board of Works. We can but wish this movement every success, though we may have some doubts thereon, when we remember the nearness of success obtained by those who strove to inaugurate the Paddington Park, and the oblivion of that project which seems now to have fallen upon all concerned. We, however, wish the good people of breezy Hampstead complete success in their praiseworthy object, which we heartily commend to the help of other dwellers in the metropolis. The high value, as health-givers and health-restorers, of heaths and commons to those who can seek their exercise and pastime thereon, is notorious; and it is matter for felicitation that these lovely spaces scattered broadcast throughout our island are likely to be jealously guarded in the future from the attacks of encroaching lords of the manor and others who would appropriate the rights of the public in order to advance their own private ends. (British Medical fournal 1884 ;i :232.) 